Ивана Д. Петковић

УДК

Докторанд Филолошког факултета ${ }^{1}$ 821.161.1-14.09 Мајаковски В. В.

Универзитет у Београду

ДОИ

https://doi.org/10.18485/analiff.2016.28.1.2

\title{
ЕЛЕМЕНТИ БАРОКНЕ ПОЕТИКЕ У СТВАРАЛАШТВУ В.В. МАЈАКОВСКОГ
}

Бројна су истраживања која потврђују везу између епохе барока и авангарде. У њима се наглашавају културно-историјске везе, сличности епоха у којима су настали (везаност обе епохе за „прелазне периоде“), коришћење сличних стилских средстава, као и сличности у њиховим поетикама.У раду ћемо настојати да утврдимо везу између њих, покажемо сличност како у културно-историјском контексту, тако и у одликама поетика обе епохе. Ову везу ћемо покушати да докажемо на примерима стихова руског футуристе В.В.Мајаковског, који је у великој мери користио каламбур, метафору и друге стилске фигуре, али и сличну графичку и звуковну организацију стиха карактеристчну за барокну епоху.

Кључне речи: барок, авангарда, футуризам, В. В. Мајаковски, Симеон Полоцки, стилске фигуре,епоха

Једна од првих сличности, коју можемо користити као показатељ везе између барока и авангарде је културно-историјска повезаност ових епоха, чињеница да су и барок и авангарда биле граничне, кризне и „нестабилне“ епохе и да су настајале у таквим историјским околностима. Управо ће ова „нестабилност“ бити утемељена у поетикама оба правца. „У периоду кризе модерне, када у привреди, политици, социјалном животу настаје нестабилност, култ разума се доводи у питање, у први план избија трагичан доживљај реалности, који не дозвољава индивидуи осећање стабилности постојања. Барок се посматра, као духовно близак, „опипљиво-близак“ период. На

*_petkovicivana1011@yahoo.com

1 Рад је прерађена и допуњена верзија рада прочитаног под истоименим нас-

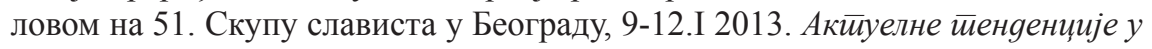
ироучавању словенских језика, књижевности и кулимура 
прелазу између XIX и XX века открили смо постојање епохе барока. Несумњиво признање барока као историјско-културне реалности-је супротна страна дубоке кризе „класичног модела културе“(Васиљева, 2001:183). Ова нестабилност је условљена и историјским околностима у којима је барок настајао: „Ако призори смрти и медитације о пролазности људског живота преплављују барокну књижевност, у томе треба видети само одраз живе стварности“" (Сује, 1988, 25). Живот је био заокупљен смрћу, каже један савремени историчар. А Монтењ (Montaigne) у једном есеју пише: „Неизвесно је где нас смрт чека, очекујмо је свуда. Припремати се за смрт значи припремати се за слободу.“ Несигурност, стрепња и меланхолија обузимају духове. На сликарским платнима, појединачним и групним портретима, видљиво је колико ова атмосфера утиче на свакодневни живот, чак и на моду: „Читава барокна Европа је у жалости“, каже Сује. „Историја одевања указује на прелазак са блиставе одежде ренесансе на шпанску моду црнине“ (32). Посебно је важно истаћи то што „упркос националним разликама, цела Европа и сва њена књижевност с краја XVI и почетка XVII века изражавају исту трагичну и прилично безнадежну визију света“" (35). Та визија, коју обично називамо барокном, универзална je, заједничка како за католике тако и за протестанте већег дела Европе (Попов, 2007:6-7).“ Иако не можемо са сигурношћу говорити о непосредном утицају барока на песнике авангарде, као и о директном преузимању поетских одлика овог правца можемо уочити низ типолошких сличности између њих. То су наговештавали и представници формалног метода у руској књижевности.

„Основу „барокне“ парадигме објашњења авангардне књижевности поставио је Ј.Н.Тињанов, који сам, колико је познато није користио термин барок. Он је нпр. писао: „Руски футуризам је био отргнут од средишње стиховне културе XIX века. Он је у својој суровој борби, у својом освајањима близак XVIII веку, пружа му руку преко главе XIX века“ (Кацис, Одески: 1994:17).

Идентичне одлике поетике оба правца су: модерност, бунт против традиције, изразита интелектуалност, негирање емоција, негирање лирског ја, рационалан однос према стваралаштву, интертекстуалност, нарушавање правила, слабљење експресивне улоге поезије, одушевљење техником, иновацијама и науком, укључивање читаоца 
у дешифровање књижевног дела. „Барокно књижевно дело је тако и устројено да привилегује примаоца уметничке поруке тако што рачуна на његову активну улогу у одгонетању и стварању смисла. И како су барокни песници подразумевали читаочеву способност схватања намерно компликованих књижевних порука (ово и јесте елитистичка, интелектуалистичка поезија, значи само за одабране), тако су и барокни писци трактата нашироко теоретисали о способности њеног декодирања. А читалац је, са своје стране, уживао у процесу и резултату дешифровања (који му се јављао као „бљесак муње“), али и у потврђивању властитог иніеенијума“ (Зоговић, 2007:19). Типске сличности између барока и авангарде Ж.Бенчић је свела на неколико основних одлика, сличних наведенима: модерност оба правца и рушење традиције, деаутоматизација рецепције уметничког дела уз помоћ метода „остранение“ и „meraviglia“, рационалност песника у коме он користи „ингениј“ тј. оштроумље и „спајање неспојивог“ као своје методе, чиме слаби експресивна и функција поезије, фокусирање на стилски, а не на тематски део текста, опадање знаковне вредности текста, тежња да се истакне графичка или акустичка страна текста (Carmina figurata Симеона Полоцког у облику звезде, срца, крста, слични стилски поступци које су користили представници барока и авангарде тj. коришћење нпр. интелектуално поентираног стила (stilus acutus) и коришћење полиптотона, парегменона, антиметабола, парономазије, кончета, оксиморон. „Моменти подударности између барока и авангарде могу се објаснити типолошки као резултат њихове припадности истом кругу уметности који се у знаности о књижевности од Курцијуса надаље најчешће обиљежава термином „маниризам“. Манирист не жели мисли изрицати обично, него необично. Маниризам се схваћа као надвременска категорија, као „константа европске књижевности“ и „комплементарна појава класици свих епоха“, а оно је заједничко свим маниризмима и маниристима, па тако и у бароку и авангарди “(Бенчић, 1991: 100). Ипак, мора се напоменути да је у различитим националним срединама, ова веза имала другачије размере.

„Веза европске књижевности XX века са књижевношћу барока, у различитим земљама је имала различите форме, које зависе од специфичности националних културних традиција. У неким случајевима, таква веза се огледала у свесној оријентацији на уметничко наслеђе XVII века, (нпр. рехабилитација Гонгоре од стране шпанских песника 
1920-их година), код других је постојала скривено, није била потврђена и документована од стране самих писаца, као што је то био случај у Русији (са ретким изузецима; делимично одушевљење Хлебњикова идејама Лајбница и сл.)“(Смирнов, 1979:335). Сам словенски и у оквиру њега руски барок је имао низ својих специфичности које су биле условљене низом чинилаца, међу којима се као најбитнији издвајају следећи: изостанак ренесансе у Русији и утицај православља које је давалоо смиренији тон руском бароку. Ове две главне разлике у односу на западноевропски барок су дале и оптимистичнији тон руском бароку. Тема смрти и распадања није била опсесија руског барока. „Славенство је мјешавином оштроумља и мистике, виталности и меланколије, весељења облику и страхопоштовања према њему (и према ,умјетности“) увелике придонијело одуховљавању и поунутрашњењењу старих формалних маниризама и маниристичких облика, мишљења у Европи (Hocke, 1984:107). Али, на смањену заинтересованост руских барокних песника за тему смрти су утицале и друге околности. ${ }^{2}$

Руски барокни песници су се ограђивали од националне старине и доживљавали своја књижевна дела као новину на руском тлу. „И барок и авангарда крше традицијом канонизиране поетске норме зато да би као највишу естетску вриједност истакли своју новину и управо тим квалитетом дјеловали на читатеља у чијој су свијести још увијек присутне поетске норме претходних формација“ (Бенчић, 1993:103). Величање значаја барокног и авангардног песника била је још једна од заједничких одлика оба правца. „Поређење света са резултатом стваралаштва-књигом, позоришном представом, сликом-отварало је могућност да се стваралц космоса упореди са уметником, чему је била наклоњена барокна мисао, или уметника са-творцем света и човечанства, као у XX веку, и прерасло је у убеђење, да владање речју или другим знаковним системом даје право на управљање догађајима (Смирнов, 1979: 341).

Унутрашња противречност обе епохе која се намеће као једна од њихових главних заједничких одлика, али је она ипак остала више симбол барока: „Маниризам је увек резултат снажних протусторежних напетости у односу према нуминозноме, према друштву, према властиту јаству“ (Hocke, 1984: 59). Барок који је подразумевао контраст,

2 Овде првенствено имамо у виду религиозно-дидактичку функцију поезије и њен дворски тј. програмски карактер. 
мада је наизглед деловао неорганизовано и хаотично представљао је свет који је унутар себе организован, и усредсређен да изазове одређено дејство на читаоца. Поред тога и барокни и авангардни (овде имамо у виду футуристе) песници, што је већ поменуто, били су усмерени на визуелну и звуковну страну својих дела и на узајамну међузависност уметности у својим делима: „Песници су у бароку и цртачи и гравери и архитекти“ (Павић, 1991:52). Емотивни набој, напетост коју је барок изазивао била је такође једна од првих уочљивих карактеристика: „Барок у нама у тренутку изазива снажно дејство, али нас оно затим убрзо напушта, остављајући за собом извесну празнину. Барок не пружа радост постојања, већ настајање, догађање. Он не пружа задовољство, већ незадовољство и неспокојство. Не осећамо избављење, већ увученост у напето стање ствари “ (Велфлин, 2000: 40).

У оквиру историјске повезаности обе неопходно је нагласити трагичан доживљај света као њихову основу: „Типске сличности између уметничких парадигми поезије авангарде и барока састоје се из блискости карактеристика основних модуса постојања, повећаном осећању за трагично, неразрешивим конфликтима и странама живота човека, које су изазване конкретном временском епохом са ратовима и социјалним ломовима. У складу са тим, код футуриста настаје трагични мотив „omnia vanitas“ облици свеопштег, неумољивог кретања ка вечности (Хлебњиков), пролазности човековог живота (Каменски), његове ништавности у поређењу са вечношћу. Представа смрти се развија на основу представе огромних катаклизми, које потресају целу планету и космос (земљотреси, поплаве), често изазивају у читаоцу потресне натуралистичке слике. Ово одговара са наглашеним натурализмом решења одговарајућих тема у поезији барока. Типске паралеле се прате у актуализацији устаљених начина и модела „свет књига“ „свет позориште“, „човек-свет у малом“. У поезији футуризма јасно је означена митологема (poeta creator), једна је од главних у поезији барока, заснована на представи о сакралној природи речи Логоса. Рад футуриста над речју, посебна пажња према његовој морфолошкој, графичкој структури, фоносемантици, узајамном односу конотативног и денотативног значења, етимологији имена дубоко је блиска тој коју је својевремено градио Симеон Полоцки, Е. Славинецки, М.Ломоносов, Г.Сковорода. У поетској пракси футуриста одража- 
вају се принципи усложњавања форме које су они прокламовали, који су били парадоксално блиски начинима ,усложњавања“ семантике и стилистике барокних текстова. Поново је актуализована стихија игре синтагме, користе се велики број стилских фигура међу којима су „оштроумна“ метафора која се темељи на спајању удаљеног, перифразе, антитезе, оксиморона, фигуре набрајња“ (Корзов, 2005). Додајмо и важност тежње ка изненађењу и необичном које су присутне како и у епохи барока, тако и у футуризму, са наглашеном тенденцијом ка „зачудном“. „Манириста неће да ствари каже нормално, него анормално. Он вештачком и извештаченом даје предност пред природним. Он жели да изненади, зачуди, засени. Док постоји само један начин да се ствари кажу природно, за неприродно постоји хиљаду начина. Стога је безизгледно и бескорисно покушавати да се маниризам споји у систем, као што се то стално чинило“ (Курцијус, 461: 1996). На сличну мисао наилазимо и код Ноckea: „Битан је елемент лијепога, оно неправилно, тј. неочекивано, само изненађење, зачудност. Изненађење (suprise) и оно неочекивано спадају у најважније потицаје данашњег пјесништва. А Марино је препоручивао stupore (запањеност) те bizzarria della novita”. „Модерна“ авангарда у „бароку“ види и признаје заправо маниристички изражен свијет, тадашње високо грађанство, узноситу, репрезантативну „снагу“ барока (wilhelminizam!). Марино хоће сјединити платонизам и аристотелизам, питагорејство и епикурејство, кршћанско учење о откупљању и магију, осјетилност и буђење побожности, очај и утјеху, свијетло и тамно, истинито и лажно, извијесност и неизвјесност. Све то не мора остајати у узајамној напетости. Човијек симбол управо свега што је проблематично, попут плиме и осеке у стању је вечног немира, у неком непојмљивом процесу, мијене између духа и природе“ (Hocke,1984:63, 36, 126,131,139).

Барокна поезија је афирмисала зачудност која је била један од њених најважнијих начина комуникације. „Obscuritas јесте једно од основних својстава барокне поезије знак њене модерности“ (Зоговић, 2007: 65). Повратак речи, бављење њеном визуелном и графичком организицијом зближавају песнике барока и авангарде. „Футуристи поричу естетски принцип.Једина истина је стварање. Озаконити право уметника да живи у свету стварања. Ако су италијански футуристи „лудо заљубљени у материју“, онда су руски у реч“(Богдановић, 1963: 95). 
„Управо то давање велике пажње речи, њеном унутрашњем садржају и графичком обликовању, а такође огроман рад са речима, приближавају стваралаштво футуриста-В.Хлебњикова, В.Каменског, А.Кручоних, В.Мајаковског са поетским искуством епохе барока. Познато је да је у XVII-XVIII веку Европа била захваћена својеврсном поплавом теоријског и практичног рада о прављењу трактата о реторици, правилима структурирања поетске речи. То је нашло одјека у различитим националним варијантама у стварању стихова и прозе, проповеди и ораторских речи- Б.Грасијана, Е.Тезаура, И.Гаљатовског, М. Ломоносова. Ипак, уместо обимних дела са обиљем илустрованих сентенци и цитата представници авангарде предлажу чланке малог обима, манифесте и декларације. Уместо широких спискова метафора, епитета и другог помоћног материјала, које су у изобиљу нудили мајстори прошлих епоха и које су улазиле у састав теоријских трактата, футуристи праве спискове и речнике својеврсне парадигме речи, које су засноване на актуализацији семантике звука и слова (у том смислу и њеног графичког приказа) исто. То је и ислустрација сопствених дела и што посебно зближава стваралаштво футуриста са поезијом барока, искуства визуелног прављења стихова и цртежа са шифрама, словима, редовима, фонтовима, (Мајаковски, Кручоних, Аксјонов, Олимпов, Игнатјев). Могуће је једним словом дати графичку слику текста. На тај начин при дијаметрално супротном садржају емблема, који припадају разним историјским епохама, сличним се представља алегоријско-знаковни принцип уметничког уопштавања“ (Заряная, 2005: 1-2). Фигуре понављања, каламбур, метафора, оксиморон биле су поново у употреби: „Каламбури су се у руском употребљавали и прије него што се та ријеч појавила у рјечницима. Барокно пјесништво обилује поступцима који доводе до каламбурских спојева и облика (парономазија, макаронски стихови, versus cancrini, carmina gryphica, палиндроми и сл.)“(Flaker, 1989:129). Ипак, требало би нагласити да не можемо говорити о циљаном систематичном преузимању елемената барокног стила од стране авангардних песника, пре су како би рекла Ж.Бенчић „последица посљедица чињенице да је авангардистичко пјесништво, као и неколико стољећа раније барокно, умањило вриједност индивидуалне субјективности, растеретило се од начела миметизма и вјеродостојности и ставило тежиште 
на моменте предметности књижевнога дјела (звук, графички облик, орнамент) и на процедуре њихова искоришћавања у процесима естетске комуникације (Flaker,1989:129). И овде се метафора издваја као најзначајнија фигура: „Метафора је маниристичком пјеснику, и како то слови већ у 17. стољећу, „краљица фигура ријечи“ „најдуховитија“, „најоштроумнија“, „најдивнија“ и „најплоднија“ (Hocke, 1984: 62).

Италијански барокни теоретичари књижевности Перегрини, Палавичини и Тезауро су издвојили четири нове категорије барокне епохе чије ћемо одјеке наћи у авангардном песништву. То су ингенијум, кончето, оштроумље и зачудност. Ингениј је један од кључних појмова епохе барока „У 17. стољећу појам ингениј задобива за разлику од античких реторика значење естетски вријдног. За разлику од интелекта, способности мисаоне, рационалне анализе, чије се дијеловање ограничава на миметичко, појам ингениј истиче се као креативни принцип, који улази у подручје фантастичког и значи способност брзог, муњевитог хватања аналогија међу најудаљенијим предметима и појавама, моћ запањујућег сабирања, згушњавања оног што не припада заједно, способност стварања огралачких комбинација, могућност глумачке, комедијашке репродукције, одважно стварање чудноватог и необичног, па чак и бјесомучног, махнитост и лудост. Супротно Аристотелову захтјеву да се у метафори не доводе у везу нити превише слични нити превише удаљени предмети, барокна метафора спаја и повезује удаљене предмете и подручја, те се у јакој метафори јасно разабире дјеловање ингенија и духовите оштроумности, а тиме и кончетозности. Барокна јака метафора врло је често остварена као concetto, односно concetti ce у сечентисличким текстовима обликују као „изражајни клишеји кроз које се у највећој могућој мјери манифестира узајамност метафорике и барока као књижевног стила“" (Fališevac, 1997: 202-204).

Идентичну тежњу налазимо и код футуриста у стваралаштву В.В.Мајаковског. „Владимир Мајаковски није случајно тако тешко градио сижее својих поема. Људи нашег времена су људи интезивног детаља-људи барока.стр. Барок, живот интезивног детаља, није порок, него одлика нашег времена. Наши најбољи живи песници се боре са том карактеристиком“(Шкловский, 1990: 443-444). Метафора је овде била кључна фигура у барокном значењу. , За ралику од иниеелекйа, иніенијум не тежи ни истини, ни добру већ новом, необичном и зачудном, односно естетском ефекту. Ошйроумље је уједно и „вели- 
ка мајка сваког ингениозног кончета, блистава светлост беседничког и поетског умећа, животни дух мртвих страница, преугодан зачин уљудних разговора, крајњи напор ума и траг божанског у људској души. Ни оштроумље тако не припада уму који трага за истином и спознајом ствари, већ, напротив, ингенијуму коме предмет како делања, тако и уживања, није толико истинито, колико лепо“ (Зоговић, 2007:16-17). А као његова последица јавља се зачудност. „А чедо иніенијума јете оштроумље којим се постиже зачудност и истовремено показује снага тог иніенијума“"(Зоговић, 2005:48). Интелектуална ангажованост песника, величање његове вештине, изједначавање процеса стварања са умећем ћемо наћи у футуризму у још истакнутијем облику, него у бароку. „С правом су у повијести уметности увијек истицали интелектуални, рекли бисмо дедалски елемент маниризма, неку скоро знанственичку хладноћу стварања уз најснажнију емоцију, неку за многе застрашну свијест“" (Hocke, 1984: 46). Овде бисмо могли додати да је за футуризам било подједнако важно већ помињано негирање лирског субјекта као карактеристике претходних епоха, емоционална дистанцираност и хладноћа песника у стварању, као негирање инспирације.

„Песник је неко ко влада вештином, а није вођен надахнућем и тренутном инспирацијом. Песникова свесност у оба случаја доводи до смањене емотивности, али је и тенденција поезије да буде друштвено ангажована. Посебно је уочљива у поезији В.Мајаковског нпр. стихови посвећени револуцији" (Бенчић,1991:29). На тематском нивоу веза између барока и авангарде је такође очигледна. Идеја да је свет позориште присутна је код В. В. Мајаковског, нпр. у поеми Рай $u$ мир. Тема страшног суда присутна је у стиховима Флауйа-кичма, Па, ийак, Достиа, Мрак.

Поред метафоре у његовом стваралаштву доминирају фигуре понављања: полиптотон, парегменон, ређе антиметабола. Ове фигуpe су праћене парономастичким ефектима. То је употреба стилских фигура идентична као и у бароку. Код Симеона Полоцког налазимо често фигуре понављања и фигуре гомилања: полиптотон, парегменон, традукцију, етимолошку фигуру, антиметаболу. Ове фигуре су биле карактеристичне и за западноевропско барокно песништво. Поред поменутог С.Полоцки користи и синатксички паралелизам и енумерацију и фигуре обртања, на првом месту хипербатон, а честе су и фигуре проширивања међу којима је најважније поређење. Његова 
метафорика је за разлику од западноевропске у функцији „доброг реторичког стила“ и служи да обогати стил, али нема самосталну функцију и не служе изградњи текста, чак ни метафора и поређење. ${ }^{3} \mathrm{C}$ обзиром на то да је великим делом његово дело било програмског карактера намењено двору, свакодневном животу и образовању није смела долазити до изражаја песникова емоционалност или лични однос према тематици. На то је утицала и јака веза са реториком и велики значај реторике у барокном песништву. А у руском футуризму смањена емоционалност песника је условљена друштвеном ангажованошћу песника и појавом нових форми поезије као што су плакатна поезија, фељтони у стиховима, рекламни стихови. И барок и авангарда су усредсређени на стилски, а не на тематски део дела, па отуда богатство стилским фигурама, а само ширење текста није повезано са ширењем тематике, и тематски део је подређен стилском у обе епохе. Ова тенденција је још наглашенија у авангарди. Ово смањено вредновање знаковне стране текста ће довести до тога да и у бароку и у авангарди текст тежи томе да буде схваћен као ствар.

„Поезија руског футуризма, пре свега Хлебњикова и Мајаковског, управо обилује новим облицима речи, измишљеним речима, грађеним на основу постојећих језичких могућности аналогијом према постојећим лексичким облицима (Богдановић, 1963:85).

Развијена метафора је присутна у целокупном стваралаштву В.В.Мајаковског после 1923. „Да би тко направио добре метафоpe, мора се удаљити од „обичнога“ и тражити оно „ријетко“(Hocke, 1984:23,65). Његова реализована метафора је у исто време и израз хиперболичног доживљаја стварности, извођење појма реалног до крајњих граница буквалне конкретизације. Како је метафора најкарактеристичнија стилска фигура барока код С. Полоцког (њеног најзначајнијег руског представника) налазимо поред генитивних метафора у Рифмолоїиону и Верйоїраgу мноіоцвейном и метафоре

3 У стваралаштву Симеона Полоцког не можемо у потпуности говорити о епохи барока, тј. његова дела не припадају у потпуности овом правцу. То је условљено тиме што је барок на прелазу од западноевропске књижевности у руску претрпео знатна осиромашења и имао је другачију функцију у руској књижевности. Она је и даље већим делом била окренута средњем веку и служила је првенствено двору и његовом јачању као и то да је имала дидактичко- просвтитељску улогу. У складу са овом функцијом је смањена емоционалност у његовом стваралаштву. 
које су блиске западноервропском типу метафора. Ипак, већим делом стваралаштво Симеона Полоцког је окренуто стилским срдствима средњег века, па су метафоре како је Ж.Бенчић рекла су „сведене и без велике естетске аутономије.“ А, неоспорна веза са западноевропским бароком је присуство генитивне, предикативне и аналошке метафоре у стваралаштву С. Полоцког. „Неке од најједноставнијих метафора које је користио су повезане са црквеном литературом нпр: светло вере, мрак невере, зраци побожности. Осим тога Симеон Полоцки је користио и „спојеве метафоричког номинатива са генитивом у доследном значењу. На примијер, вода блуда, праћка молитве, жерава тијела. Удаљеност међу половима наведених метафора допушта да се оне успореде са смијонијом метафориком западноевропског барока (Бенчић, 1991:64). Сличне примере метафора налазимо у стваралаштву В.В.Мајаковског

„А душа моја

ко криее облака палих

у изгорелом небу

на зарђалом крсту неба стоји!

(Мајаковски, 1985:21)

„Вама завештавам воћњак

своје велике gуше.“

(Мајаковски, 1985: 25)

И код њега налазимо примере обилног коришћења генитивних метафора, што повезује његову поезију са стваралаштвом С.Полоцког: „лептир срца (Нате), паметна њушка трамваја (Надоело), копито молитве (За женшиной), њушка неба се широко развлачи, образи океана (А бисте ли могли), прслук душе... Ове фигуре се заснивају на начелу неспојивог. Зато су оксиморони чести у бароку (живи мртваци

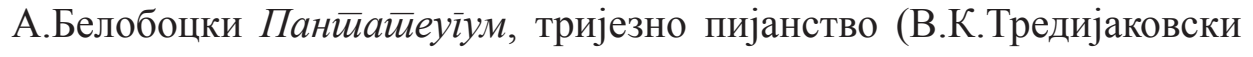
Oga o cgaче їopoga Гgанска хладни пламен (М.В.Ломоносов Вечернее размышление)“ (Бенчић, 1991:111). Распрострањену употребу генитивне метафоре примећујемо и у Облаку у йанйалонама:

„ ја сам згрчена іомила жила

јер више није важно ни то што сам од бронзе

ни што сриее мојеод ивожђа хлаgної бије 
…

Опет и опет

чекам,

забивши лице у рохаво лице кише

....

....у желе облака мрешкавих

замакати очи одебљале, а?

(Мајаковски, 1997:24-25; 45)

„Ево пар генитивних метафора из опуса Симеона Полоцког с једне стране и Владимира Мајаковског с друге: „вода блуда“ (Фебра), „праћка молитве“( Оружие 1), ,жерава пути“ (Жен близосӣь, 3), „црви гријеха“ (Клевейник); „флаута олука“ ( $A$ вы, мойли бы?), „Копито

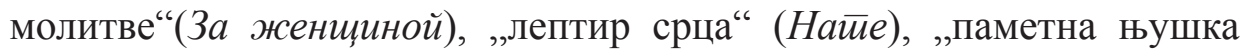
трамваја““ (Наgоело)“ (Бенчић, 1990: 110). И барокни песници као и футуристи су користили парономазију.

„Люба есть, любовь любимому богу (С.Медведев)“

(Бенчић, 1990: 111)

Код В.В.Мајаковског, ипак у нешто сведенијем облику:

„дуван сам

данас оставио“

(Мајаковски, 1997: 94)

„света освето моја“

(Мајаковски, 1985:25)

У стваралаштву В.В.Мајаковског је честа употреба полиптотона и парегменона

„милион огромних, чистих љубави

и милион милиона малих љубави“

(Мајаковски, 1970: 54)

„сједи, плачи,

Нилом, нилуј.

(Мајаковски, 1997: 61)

И као најзначајнији за барок кончеш̄о налазимо и у стваралаштву В.В. Мајаковског

„Ви мислите, бунца маларија?

(Мајаковски, 1997:24)

„Улица се провалила ко нос сифилистика“ 
(Мајаковски, 1970:26)

Код барокних песника:

„Не обретох где склонити главу мою зла игра идет,

Шахом небо хочешь взяти, мат ты скоро в аде будет

(Бенчић, 1990: 112).

Барок и футуризам су познати и по употреби оксиморона:

„Кад бих

био мали

ко Велики океан

...

о кад бих

био тих

као громови-“

(Мајаковски, 1985:26) и у називу песама: Плитика филозофија на яубоким местиима...

У барокном песништву: “живи мртваци (А. Белобоцкиј,

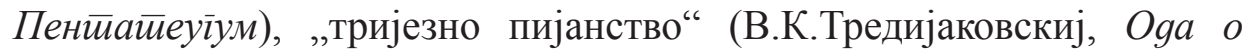
сgаче іороgа Гgанска), „хладни пламен“(М.В. Ломоносов, Вечернее размыиление)“(Бенчић, 1990: 111)

И друге фигуре понављања као нпр. анафора и епифора су биле заступљене у његовом стваралаштву:

„О слава, слава, слава херојима!!!““

„Шапе јела,

шапе,

шапице....

(Мајаковски, 1997:85, 81)

„, Од прозора руди.

Од прозора огањ зрачи.

Од прозора на уснули град густо сунце лије.“

(Мајаковски, 1985:25)

„, Младићки весело

Идемо!

Идемо!

Идемо! 
Заставу црвену, златну

носимо.

Носимо!

Носимо!

(Мајаковски, 1997: 89)

“ Из најглувљих

места

ишли су

тада

прадеди

и
(Мајаковски, 1997: 82)

Осврнимо се укратко и на метафору као најзначајнију барокну фигуру у стваралаштву В.В.Мајаковског. „Мајаковски се „попут Гуливера“" кретао кроз опојну бујицу азијанских метафора“(Hocke, 1984:106). „,асфалт као стакло

идем и звоним“

(Мајаковски, 1985: 59)

муюа-иеелеірам

очњак-клешита

(Мајаковски, 1985:46, 15)

„А ви,

да л бисте могли ноктурно

извести

на флауии-олуку?

(Мајаковски, 1970: 25)

, Гледајте-

звезде су опет обезглавили

и небо окрвавили од покоља!

(Мајаковски, 1970:59)

sygu-лађе

(Мајаковски, 1970:93)

„Сашићу себи црне панталоне

од меке каguфе свога їласа.

А жуту блузу од три аршина дуге.“ 
...

„На сииаклу асфалий пркосим-харашо!“

(Мајаковски, 1985:16)

„А речи моје-суво лишће-“

(Мајаковски, 1985:29)

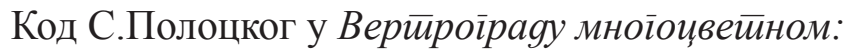

„Мир сей приукрашенный - книга есть велика“

Овај свет улепшан-је књига велика

(http://www.portal-slovo.ru/philology/37362.php)

Гласовна метафора у стиховима Писмо драгој Молчанова В.В.Мајаковског

„Прекратите ваши трели!

Я не знаю я стара ли

но вы

Молчанов,

постарели,

вы

и ваши пасторали

Риме трели, стара ли и постарели приправљају једно значење што се затим римом асоцира с појмом пасторали, чија се посве значењска компонента тиме појачава и истиче“ (Flaker, 1989:19).

Ако упоредимо употребу каламбура у стваралаштву B.В.Мајаковског ињихово коришћење код барокних песника примећујемо да су заступљенији код В.В.Мајаковског: „Интерес за говорну игру и, прије свега, за каламбур у пријиметном је порасту првих десетљећа $\mathrm{XX}$ стољећа. C теоретског стајалишта каламбуром се не баве само формалисти него и будетљанин Хлебњиков, скупља их Кручоних. Каламбуре употребљавају након Мајаковског врло радо и с великом вјештином футуристи и конструктивисти“" (Flaker, 1989:134).

Код В.В. Мајаковског налазимо низ каламбура нпр.

„На пороге новой жизни

заимемся подведением итогов, сверкой

сводкой

/На прагу новог живота, забавимо се свођењем резултата провјеравањем, извјештајем. Други: Точно, с вотком, забавимо се вотком пример сложеног каламбура 
,Там

за горама горя

солнечный край непочатый

за голод

за мора море

шаг милионый печатай

Гончаров: 182

(Flaker, 1989:133)

/тамо за брдима недаћа, сунчани је крај неначете, за глад за помора море, миљунски корак отискуј/ „Афирмиран мајстор каламбурске игре ријечима био је В.Мајаковски. Њему су, као што сам рекао, „пуна уста /природних љепота“" (полон рот/красот природ). Мајаковски је мајсторски успијевао пренијети дојмове и мисли прецизним и добро погођеним, неријетко гротескним, али увијек необичним и дојмљивим изразима, неологизмима, помацима и „размацима“ („раздвиг“"), користећи се притом свеукупним дијапазоном каламбурске игре ријечима. Прилично често Мајаковски користи каламбурске дублете пропуштајући једно слово:

охала-заглохла (кукала је- умукла је)

смотрел как -тарелка (гледао је како -тањур)

непачка- не пачкая (НЕП-киња- не мрдајући)

По истом принципу написана је и пјесма: Из улище у улицу (1913)

$\mathrm{Y}-$

лица

Лица

$\mathrm{y}$

догов

годов

рез

че

Че

pe3

железных коней

( У-/лица/ Лица/на/ догама/ од година/ су ош/трија/Пре-/ко/гвоздених коња/.../)

Појављују се и у насловима песама Иниеернационална басна 
1917. Мајаковски је наглашавао да је управо у изразито сатиричној

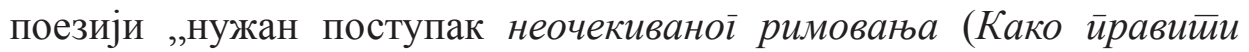
cйuхове).У Мајаковскога се тај поступак често темељи на каламбуру (Flaker, 1989:145-147).

Свесно жртвовање и одрицање личног налазимо у стиховима В.В.Мајаковског Во весь іолос

но я

себя

смирял

становясь

на горло

собственной песне

(но ја, себе сам кротио, стајући на грло, властитој пјесми). Овде примећујемо губитак песничког лирског субјекта и изградње новог песничког језика, антисубјективистичког. О тој тенденцији су писали у свом манифесту Слово как йаковое, где се наглашава да они више мисле о речи, за разлику од њихових претходника који су се сувише бавили душом. „Песници руске авангарде често показују спремност да се одрекну индивидуалнога. За многе руске умјетнике првих десетљећа XX стољећа, као и за њихове западноевропске сувременике, на примјер, карактеристично је да своју дјелатност развијају у оквиру одређених праваца и покрета, формираних око каква заједничког програма“" (Flaker, 1987:125).

Ослањајући се на бројна ранија истраживања и утврђене постојеће везе између барока и авангарде, покушали смо да укажемо на сличност између барокне епохе и авангарде. Осврнули смо се и на историјско-културни контекст, на сличност између периода настанка ових праваца, тј. њихову повезаност са „прелазним периодима“, као и на саму „граничност“ као кључну историјку карактеристику обе епохе. У оквиру веза између барокне епохе и авангарде на нивоу поетике настојали смо да покажемо специфичност руског барока у односу на западноевропски барок (поред постојеће сумње и полемика о његовом постојању у Русији) и на утицај руског барока на авангарду, на примеру стваралаштва футуристе В.В.Мајаковског. Сличности које постоје између њих се могу протумачити с једне стране као последица припадања истом $\bar{u} u \bar{u} y$ уметности.

Установили смо да се као заједничке одлике оба правца 
код више истраживача јављају: модерност, зачудност, негирање традиције, интелектуалност, смањена експресивна улога поезије, укључивање читаоца у дешифровање текста, негирање лирског ја, наглашавање звуковне стране текста, удаљавање од значењског дела текста и оријентисаност на његову звуковну страну, слична графичка организација текста, која је ипак била израженија код представника руског барока (она је комплекснија у стваралаштву Симеона Полоцког, него код В.В. Мајаковског, (могу се нпр.погледати његови стихови у облику срца, крста, пехара, звезде, итд.). Највећа подударност на коју смо настојали укажемо је на нивоу стилистике. Ипак, као што је употреба метафоре била смањена у руском бароку и била првенствено одлика западноевропског барока у коме је постојала у знатно развијенијем облику, тако бисмо могли закључити да је употреба полиптона, парономазије, каламбура, гласовних метафора, анафоре и епифоре у већој мери карактеристична за стваралаштво руских футуриста код којих се појављује у знатно развијенијем облику него код представника руског барока. На примерима стихова В.В.Мајаковског и руских барокних писаца првенствено С. Полоцког, покушали смо да утврдимо сличност између њихове поезије на стилском, текстуалном и тематском нивоу. Сличност у одабиру тема код барокних песника и руских авангардних песника, може се правдати припадањем истом типу уметности, али и самом настајању епоха у кризним периодима. Ипак, на тематском нивоу постојале су и одређене разлике, тема страшног суда, смрти била је мање карактеристична за стваралаштво В.В. Мајаковског, него С.Полоцког што можемо оправдати тиме што је В.В. Мајаковски припадао футуризму, који је пропагирао регенерацију, физичку снагу, величао силу, па због тога није био толико усмерен на смрт, пропадање и труљење колико је то био барок, првенствено западноевропски барок, jep је ова тема била мање заступљљена у руском и источноевропском бароку. И други специфично барокни мотиви и теме као што су пролазност, непостојаност и несталност свега земаљског у мањој мери су заступљене код авангардних песника и не бисмо могли тврдити да представљају везу између имеђу стваралаштва В.В.Мајаковског и барока. Величање стваралачког чина песника је заступљено и у бароку и у футуризму, с тим што можемо закључити да је футуризам у већој мери затупао идеју иесник-Боі, а да је величање песникове личности 
пре одлика футуризма, него барока, што објашњавамо религиознодидактичком усмереношћу руског барока. Сличности су очигледне и у одабиру других мотива као што су: мотив огледала, свет-позориште, поређење света са резултатом стваралаштва-књигом, шах (иако се неки од мотива јављају код других песника: О. Е. Мандељштама, Б. Л. Пастернака и др.).

И као кључну духовно-историјску везу наводимо прикривено трагичан доживљај света обе епохе. „У једној блиставој, засењујућој спољашњости крије се тама човекове интиме, његових стрепњи и разочарања. Суморни дух тражио је светла, посежући за обећавајућим сјајем, али се он испостављао као краткотрајна илузија, после које настаје још дубља тама: „Свећа се угасила и ми остасмо у мраку“, каже Луда у Шекспировом Краљу Лиру (Попов, 2007:17).

\section{Литература:}

Benčić, Ž. (1991). Barok $i$ avangarda.Zagreb: Zavod za znanost o književnosti Filozofskog fakulteta.

Bogdanović, N. (1963). Futurizam Marinetija i Majakovskog. Beograd: Prosveta. Velflin, H. (2000). Renesansa i barok.Prevela Branka Raljić.Sremski Karlovci, Novi Sad:Izdavačka knjižarnica Zorana Stojanovića.

Заряная, И. С. (2005). Иірровая йоэйика Василия Каменскоїо в зеркале барокко, Киев, Литературная газета 22.

Zogović, M. (2007). Barok, književna teorija i praksa.Beograd: Alfa, Narodna knjiga.

Zogović, M. (2005). Književno-teorijska misao italijanskog baroka u Radivoj Stokanov, Dometi br.122/123(str.47-64). Sombor: Narodna biblioteka „Karlo Bjelicki““

Корзов, Ю. И.(2005). Русская йоэзия ХХ сииолейия в кониеексиее gи-

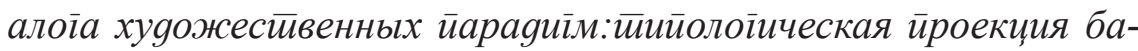
рокко в аванїарgе и йосймоgернизме.Киев: Киевский национальный университет им. Тарас Шевченко

Курцијус, Е. Р. (1996). Евройска књижевности и лайински среgюи век. Београд: СКЗ

Majakovski, V. V. (1985). Ja lično.Beograd: Prosveta 
Мајаковски, В. В. (1997). Облак у йанйалонама.Београд:Књижество Мајаковски, В. В. (1970). Песме. Београд:Рад

Павић, М. (1991). Барок. Београд: Научна књига, Досије

Смирнов, И.П.(1979). Барокко и опыт поэтической культуры начала XX в. У А.Рогов, Славянское барокко: Исйорико-кульйурные ироблемы эйохи (стр.336-356). Москва: Наука.

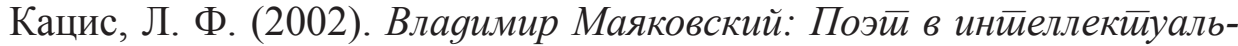
ном кониеексие эйохи. Москва:РГГУ

Попов, Ј. (2007). Барокна епоха у европској и српској књижевности у Бојана Стојановић-Пантовић, Теоријско-исйоријски йреїлеg комиараииисиичке иеерминолойије коg Срба:оїлеgна свеска бр.2 (стр. 33-58). Београд:Књижевно друштво Свети Сава.

Fališevac, D. (2007). Concetto kao pojam barokne poetike i pjesnički postupak u hrvatskoj književnosti XVII veka (str.201-228). Stari pisci hrvatski i njihove poetike. Zagreb:Hrvatska sveučilišna naklada

Flaker, A. (1984). Pojmovnik ruske avangarde.Zagreb:Grafički zavod Hrvatske, Zavod za znanost o književnosti Filozofskog fakulteta

Flaker, A. (1985). Pojmovnik ruske avangarde.Zagreb:Grafički zavod Hrvatske, Zavod za znanost o književnosti Filozofskog fakulteta

Flaker, A. (1987). Pojmovnik ruske avangarde. Zagreb: Grafički zavod Hrvatske, Zavod za znanost o književnosti Filozofskog fakulteta

Hocke, G. R. (1984). Manirizam u književnosti.Zagreb: Centar za kulturnu djelatnost

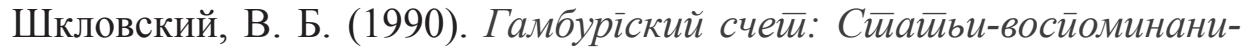
я-эссе (1914-1933):Поиски ойиимизма (стр. 443-444). Москва: Советский писатель

\section{Извори:}

Васиљева, Ж. В. (2001).Образы барокко в диалоге культурных эпох,

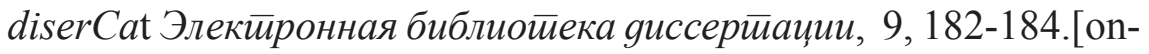
line]. Доступно преко:

http://www.dissercat.com/content/obrazy-barokko-v-dialoge-kulturnykhepokh\#ixzz3JDLxIXPK

[19.04.2015.]

Кацис, Л. Ф. Одеский, М. П. (1994). Кругом возможно Бог А.Введенского-школьная драма ? Stanford Slavic Studies, Themes and Variations In Honor of Lazar Fleishman, 8, 417-437. [on-line]. Дo- 
ступно преко:

http://www.fege.narod.ru>librarium/kazodess.htm [26.04.2015.]

Архангельская, А. В. (2005). Творчество Симеона Полоцкого (1629-

1680), Сочинения йо лийерайуре и русскому языку,

[on-line]. Доступно преко:

(http://www.portal-slovo.ru/philology/37362.php) [27.06.2015.]

Ивана Петкович

\section{Резюме \\ ЭЛЕМЕНТЫ ПОЭТИКИ БАРОККО В ТВОРЧЕСТВЕ В.В. МАЯКОВСКОГО}

В данной работе попробовали уточнить элементы связывающие эпоху барокко и авангард. Как образцовые примеры этих направлений мы сопоставили творчество самого значительного представителя русского барокко С. Полоцкого и представителя русского футуризма В. В. Маяковского. Наряду с этим, анализировали культурно-исторический фон эпох барокко и авангард и типологические сходства этих периодов. Особое внимание уделили стилистическим особенностям эпох, распространонному употреблению метафор. Замечаем, что связь между барокко и футузизмом существует одновременно как и на культурно-историческом уровне так и на стилистическо-тематическом уровне. 